Лінгводидактичні стратегії: проектування процесу навчання української мови у вищій школі : [монографія]/ Олеся Вадимівна Любашенко. - Ніжин : Аспект Поліграф, 2007 . 296 с. 10. Методика навчання української мови в середніх освітніх закладах / [Пентилюк М. І., Караман С. О., Караман О. В. та ін.] ; за ред. М. І. Пентилюк. - К. : Ленвіт, 2009. - 400 с. $\quad$ 11. Тоцька Н. Л. Формування професійно зумовленого мовлення студентів технічного ВНЗ (з технологічних спеціальностей легкої промисловості) : дис. ... канд. пед. наук : 13.00.02 / Тоцька Наталія Леонідівна. - К., 2001. - 215 с. 12. Українська мова за професійним спрямуванням : навч. посіб. [для студ. вищ. навч. закл.] / Караман С. О., Караман О. В., Копусь О. А., Тихоша В. І. та ін.; за ред. С. О. Караман, О. А. Копусь. - К. : Літера ЛТД, 2013. - 544 с.

УДК 37.015:06.053.52:331.105

Оксана Тур

\title{
ФОРМУВАННЯ КОМУНІКАТИВНИХ УМІНЬ МАЙБУТНІХ ДОКУМЕНТОЗНАВЦІВ НА ОСНОВІ СОЦІАЛЬНОГО СПІВРОБІТНИЦТВА АКАДЕМІЧНИХ ГРУП
}

Тур О. М. Формування комунікативних умінь майбутніх документознавців на основі соціального співробітництва академічних груп.

У статті визначено поняття «комунікативні вміння», «соціальне партнерство», «академічна група», виокремлено мовленнєві, діалогові, презентаційні типи комунікативних умінь, з'ясовано етапи і принципи їх формування у студентів вищої школи.

Ключові слова: комунікативні вміння (мовленнєві, діалогові, презентаційні), соціальне співробітництво, академічна група.

Тур О. М. Формирование коммуникативных умений будущих документоведов на основе социального сотрудничества академических групп.

В статье определены понятия «коммуникативные умения», «социальное сотрудничество», «академическая группа», выделены речевые, диалоговые, презентационные типы коммуникативных умений, представлены этапы и принципы их формирования у студентов высшей школы.

Ключевые слова: коммуникативные умения (речевые, диалоговые, презентационные), социальное сотрудничество, академическая группа.

Tur O. M. Formation of future documentalists' communicative shills on the basis of academic groups social collaboration.

The article defines the notions of «communicative skills», «social partnership», «academic group», determines the language, dialogue and presentation types of communicative skills; presents the stages and principles of forming the skills in high school students.

Key words: communicative skills (language, dialogue, presentation), social collaboration, academic group.

В умовах реформування вищої освіти й переходу на багаторівневу підготовку професійних кадрів особливого значення набуває якісне формування у студентів комунікативних умінь, високий рівень яких $є$ необхідним не тільки для успішного навчання в сучасній вищій школі, але й задля формування особистості творчої, 
соціально орієнтованої, мобільної, такої, що почувається впевнено в різних ситуаціях ділового й побутового спілкування, зокрема й на міжкультурному рівні, уміє і може працювати в команді, підготовлена до професійної самопрезентації.

Сучасні дослідження свідчать про недостатню розвиненість комунікативних умінь студентів [3], зокрема майбутніх документознавців [9]: вони не володіють технологією проведення ділових зустрічей, бесід, переговорів, уміннями активно слухати, моделювати власну позицію і ставлення до неї партнера, встановлювати міжособистісні й ділові контакти. Значні труднощі пов'язані з володінням мовою як засобом спілкування: організацією початку висловлювання, розташуванням його окремих частин, логічною побудовою викладу, правильним розгортанням обраної синтаксичної конструкції, добором і використанням синонімічних варіантів тощо. У мовленні багатьох студентів наявні жаргонізми, вульгаризми, просторічні елементами, що свідчить про недотримання норм мови. Невиразне, фонетично неправильне мовлення, порушення логіки його побудови, невиправдані міміка, жести негативно впливають на співрозмовника, нівелюють авторитет мовця, викликають взаємну недовіру, знижують ефективність спілкування, в окремих випадках навіть зумовлюють його припинення. Більшість студентів погано володіє вміннями публічного виступу, презентації і самопрезентації. Отже, необхідним $\epsilon$ застосування сучасних підходів до формування комунікативних умінь студентів.

Mema cmammi- виявити організаційно-педагогічні умови соціального співробітництва академічних груп, які сприяють ефективному формуванню комунікативних умінь студентів.

Питанням формування комунікативних умінь присвячено дослідження як вітчизняних науковців (С. Бондаренко, М. Васильєва, І. Воробйова, Л. Дарійчук, 3. Дзюбата, М. Ісаєнко, В. Кручек, Н. Плешкова, Л. Савенкова, Т. Шепеленко, О. Янишина та ін.), так і зарубіжних (І. Зимня, Н. Кузьміна, Н. Косова, Я. Колкер, Г. Китайгородська, І. Максимова, Р. Мильруд, Ю. Пассова, Г. Рогова, М. Холодна та ін.). Вивчення у психолого-педагогічній і лінгводидактичній літературі проблем формування комунікативних умінь студентів зумовлено пошуком способів підвищення рівня загальної комунікативної культури, якості й ефективності навчання й соціалізації студентської молоді в умовах формування єдиного освітнього простору і глобального ринку праці.

Дослідники по-різному трактують комунікативні вміння. Як зазначає Ю. Жуков, «..одні розуміють під уміннями, перш за все, поведінкові навички, інші - здатність розуміти комунікативну ситуацію, треті - здатність оцінювати свої ресурси i використовувати їх для розв'язання комунікативних задач» [4]. Переважно під комунікативними вміннями розуміють уміння спілкування, безпосередньої й опосередкованої міжособистісної комунікації. Традиційно комунікативні вміння - це вміння правильно, грамотно, дохідливо пояснити свою думку й адекватно сприйняти інформацію від партнерів по спілкуванню [8]. Ми визначаємо комунікативні вміння як складні структурні поєднання засвоєних способів здійснення комунікації, що виявляються у свідомому, доцільному виконанні всієї системи перцептивних, мисленнєвих, мнемічних, вольових, сенсомоторних та інших дій, які забезпечують успішність комунікативної діяльності у різних умовах її перебігу.

Одним 3 ефективних засобів формування комунікативних умінь студентів, на нашу думку, $\epsilon$ соціальне співробітництво (партнерство) академічних груп, що пов'язано 3 визначеною в суспільстві тенденцією дефіциту спілкування 3 представниками своєї чи іншої лінгвокультурної спільноти. 
Соціальне партнерство - одна 3 форм взаємодії, яка почала стрімко розвиватися останнім часом, що підтверджують дослідження С. Валуєва, О. Ігнатьєва, Е. Нестерова, Г. Семигіна та інших $[1 ; 5 ; 7]$. У науковій літературі й практиці соціальне партнерство визначається як специфічний тип суспільних відносин між соціальними групами, прошарками, класами, спільнотами та іншими соціальними суб'єктами, характерною ознакою якого $\epsilon$ спрямованість на узгодженість інтересів цих суб'єктів із питань регулювання стосунків [2]. В освітній діяльності вищої школи може бути організоване співробітництво академічних груп студентів, наприклад, однієї спеціальності чи напряму підготовки (внутрішній рівень), різних спеціальностей чи напрямів підготовки на одному факультеті (проміжний рівень) або різних факультетів (зовнішній рівень), що дозволить підвищити ступінь розвитку комунікативних умінь студентів, а отже, буде сприяти підвищенню якості підготовки випускників закладів вищої професійної освіти.

Академічну групу ми визначаємо як контингент студентів, які здійснюють навчання за однією спеціальністю чи напрямом підготовки, в один час і складають мінімальну навчальну одиницю. Академічна група - це соціальне утворення, у процесі функціонування якого здійснюється соціально-професійне формування майбутніх спеціалістів.

Студентів в академічній групі поєднують: загальна мета й завдання професійної підготовки, спільна навчально-професійна діяльність, зв'язки ділового й особистісного характеру, однорідність складу групи за віком, обмежений терміном навчання у ВНЗ час роботи групи, високий рівень студентського самоврядування, висока поінформованість один про одного, активна взаємодія у процесі комунікації. Між студентами академічної групи встановлюються функціональні зв'язки, які визначаються розподілом функцій, емоційні зв'язки, або міжособистісні комунікації, які виникають на основі симпатій, загальних інтересів. Цілісними характеристиками студентської академічної групи є такі показники, як: інтра- та інтегрупова активність, референтність, згуртованість, психологічний мікроклімат тощо [6, с. 104-107].

Соціальне співробітництво академічних груп $\epsilon$ сумісною колективною діяльністю студентів, спрямованою на формування системи стійких, соціально значущих взаємовідношень, які сприяють підвищенню рівня навчальної мотивації, активності, особистісному i професійному розвитку студентів. У результаті взаємодії студентів різних академічних груп відбувається активний обмін інформацією, формування комунікативних якостей учасників. У спілкуванні 3 однолітками студенти можуть утвердитися у правильності обрання свого фаху, своєї ролі й місця в галузі майбутньої професійної діяльності. Успішність реалізації себе у спілкуванні, ефективність спілкування у студентському віці відіграють важливу роль у формуванні комунікативних умінь.

Інтерес сучасної науки до проблем формування комунікативних умінь зумовив появу різних їх класифікацій, головною відмінністю яких $є$ критерій, відповідно до якого зроблена систематизація. Найпоширеніша класифікація об'єднує два блоки вмінь - загальних та спеціальних, кожен із яких має чітку структуру. До блоку загальних умінь належать слухання й говоріння. До спеціальних віднесено вміння, необхідні для професійної діяльності: провести презентацію, семінар, ділову бесіду, організувати виробничу нараду, інструктування підлеглих тощо. Обидва блоки містять вербальний та невербальний складники [4]. Розроблено більш детальну класифікацію комунікативних умінь, наприклад, уміння проводити консультації, працювати з групою, вести телефонні переговори, оцінювати себе, інших, колектив, процеси, події, організовувати позитивний зворотній зв'язок тощо [8]. 
Ми виокремлюємо три типи комунікативних умінь - мовленнєві, діалогові, презентаційні. Мовленнєві вміння передбачають оволодіння нормами сучасної української літературної мови, дотримання певних вимог, що виявляється у правильності побудови фраз, точності, багатстві, змістовності, логічності та ясності викладу думок, образній виразності мовлення, його доцільності, доступності, чистоті, естетичності. Діалогові вміння - це вміння правильно сприймати й розуміти партнера по спілкуванню, володіння прийомами активного слухання, яке передбачає активний зворотній зв'язок задля контролю точності сприйняття почутого (звернення до співрозмовника за уточненнями та постановка перед ним відкритих запитань; відтворення частини висловлювання партнера або всієї його фрази; перефразування висловлювання; резюмування), добір мовленнєвих засобів залежно від ситуації спілкування, вміння домовлятися 3 партнером, уникати конфліктів у спілкуванні. Презентаційні вміння - це, передусім, уміння виступати публічно, а також презентувати себе в різноманітних ситуаціях.

Відповідно до виокремлених типів пропонуємо формування комунікативних умінь студентів проводити у три етапи: 1) формування мовленнєвих умінь; 2) формування діалогових умінь; 3) формування презентаційних умінь. Кожен етап повинен реалізуватися в навчальній і позанавчальній діяльності майбутніх фахівців.

У процесі реалізації першого (мовленнєвого) етапу необхідно організовувати спільні навчальні заняття для студентів різних груп як однієї спеціальності чи напряму підготовки, так і різних. На таких заняттях особливу увагу слід приділяти грамотності мовленнєвих висловлювань студентів, виправленню типових помилок, контролювати емоційну виразність, точність, доцільність мовлення тощо. Наприклад, у межах дисципліни «Вступ до фаху» на одному із занять для майбутніх документознавців можна організувати дебати на тему «Імідж сучасного працівника служби документації», під час яких студенти матимуть змогу відстоювати свою позицію, наприклад, щодо особистісних характеристик інформаційного менеджера, значення зовнішнього вигляду у створенні іміджу документознавця тощо. Особливе місце повинно відводитися програванню різних ситуацій, під час яких відбуватиметься тісна взаємодія студентів різних академічних груп. Можна організувати факультативний курс «Естетика мовлення», на якому підготовка до занять буде здійснюватися разом із викладачем і мікрогрупами студентів.

Задля формування комунікативних умінь у позанавчальній діяльності можна організувати, наприклад, підготовку i проведення студентськими групами майстерень для своїх однокурсників чи студентів інших факультетів із формування культури мовлення, наприклад, із таких тем: «Самовдосконалення особистості як основа розвитку культури ділового спілкування інформаційного менеджера», «Слова-паразити: як 3 ними боротися» тощо. Також позитивні результати може засвідчити організація студентського радіо та телебачення, де диктори та кореспонденти розвиватимуть свої мовленнєві вміння.

На цьому етапі студенти повинні досконало оволодіти нормами сучасної української літературної мови, знати основні вимоги до мовлення і постійно дотримуватися їх у будь-якій ситуації спілкування.

На другому етапі увагу слід звернути на розвиток діалогових умінь студентів: умінь домовлятися 3 партнером, будувати конструктивну взаємодію. Задля цього можуть бути використані такі завдання: відтворіть діалог у ситуації, коли керівник підприємства робить зауваження спеціалісту кадрової служби щодо якості виконаного ним доручення або звільняє 3 роботи підлеглого, який систематично порушує трудову дисципліну. 
Однак акцент на цьому етапі більшою мірою необхідно поставити на оволодіння студентами прийомами активного слухання, оскільки згідно 3 даними досліджень, у процесі спілкування людина в середньому витрачає 42-53\% часу на слухання і тільки 16-32\% - на говоріння, 15-17\% - на читання, 9-14\% - на письмо. Хоча слухання забирає більше часу, ніж інші види комунікативної діяльності, його ефективність становить тільки 25\%, тобто $75 \%$ інформації втрачається. Навичками ефективного слухання володіють не більше $10 \%$ людей [10, с. 144]. Задля підвищення ефективності слухання необхідно удосконалювати навички концентрації уваги, емоційного самоконтролю, роботи 3 інформацією. Задля цього доцільно використовувати такі завдання: 1) слухання з метою розуміння інформації (пошук ключових слів і фраз, що в узагальненому вигляді формулюють основні проблеми); 2) слухання задля аналізу й оцінювання інформації (розпізнавання помилок в аргументах і твердженнях адресанта, розрізнення фактів та оцінок); 3) слухання задля запам'ятовування інформації [10, с. 144-145].

Окрім того, увагу слід звертати і на формування умінь невербального спілкування, оскільки невербальні реакції відбуваються на рівні підсвідомості, що вимагає додаткових зусиль задля формування свідомих умінь відповідного використання цих реакцій. Приклад завдання: пригадайте значення невербальних засобів спілкування і проаналізуйте мікроситуацію: «Ви на прийомі у керівника, сидите за приставним столом значно меншого розміру, ніж його стіл. Слухаючи Вас, керівник склав руки пірамідою, опершись ліктями на стіл. Потім керівник узяв у праву руку окуляри і став похитувати ними перед своїм обличчям на рівні підборіддя. Через п’ять хвилин він стрімко підвівся i, не сказавши ні слова, вийшов у приймальню. Який стан керівника і його ставлення до Вас відображали ці жести?».

Також на цьому етапі групи студентів різних курсів і спеціальностей можуть здійснювати підготовку олімпіад, науково-практичних конференцій, навчальних семінарів тощо.

Позанавчальна діяльність може характеризуватися активною участю академічних груп у роботі лабораторії соціального проектування, де студенти матимуть змогу створювати й реалізувати актуальні соціально орієнтовані проекти. Задля розвитку діалогових умінь діяльність студентів слід спрямувати на підготовку і проведення кураторських годин, факультетських та університетських заходів (Дня знань, Дня студента, зустріч випускників тощо).

Очікуваними результатами формування комунікативних умінь на другому етапі $\epsilon$ набуття студентами вмінь правильно сприймати і розуміти партнера по спілкуванню, володіти невербальними засобами спілкування, прийомами активного слухання, добирати мовленнєві засоби залежно від ситуації спілкування, домовлятися $з$ партнером, усувати конфлікти під час спілкування.

Реалізація третього етапу має на меті формування і розвиток презентаційних умінь студентів. Для цього підсумковий контроль - екзамени і заліки - доречно організовувати в нетрадиційній формі, наприклад, студенти-старшокурсники беруть участь в оцінюванні відповідей студентів молодших курсів, також можна застосовувати прийоми самооцінювання і взаємооцінювання.

У позанавчальній діяльності студентські групи-партнери можуть організовувати конкурси дослідницьких робіт студентів, де оцінюється якість доповідей, відповідей на поставлені питання, конкурс ораторської майстерності, день відкритих дверей із презентацією свого факультету, своєї спеціальності чи напряму підготовки тощо. Також змішані мікрогрупи студентів різних курсів можуть проводити профорієнтаційну роботу у школах, коледжах, технікумах та інших закладах освіти. 
Результатом роботи на презентаційному етапі мають стати сформовані уміння студентів виступати публічно $з$ доповідями, повідомленнями, презентувати себе в різних ситуаціях.

Формування комунікативних умінь студентів - майбутніх документознавців у процесі соціального співробітництва академічних груп повинно здійснюватися на основі: 1) взаємовигідної спільної діяльності, що є центральним принципом у побудові соціального співробітництва, оскільки партнерські стосунки спрямовані на отримання певної користі, збагачення чимось необхідним кожною зі сторін, які взаємодіють; 2) добровільності, тому що участь у партнерській взаємодії не повинна нав'язуватися, інакше не буде мотивації для ефективної взаємодії, що не дозволить досягти поставленої мети - розвинути комунікативні вміння студентів; 3) активності суб'єктів соціального партнерства, оскільки запорукою формування будь-яких умінь, зокрема комунікативних, є діяльнісний підхід; 4) комунікативної рівності учасників, що проектує побудову суб'єкт-суб'єктних відношень; 5) відкритості академічних груп для взаємодії.

Отже, для формування високого рівня комунікативних умінь студентівдокументознавців $є$ необхідними такі організаційно-педагогічні умови: 1) організація соціального партнерства академічних груп на зовнішньому, проміжному і внутрішньому рівнях; 2) комплексне формування комунікативних умінь на мовленнєвому, діалоговому та презентаційному етапах як у навчальній, так і позанавчальній діяльності студентів; 3) дотримання принципів взаємовигідної спільної діяльності, добровільності, активності, відкритості, комунікативної рівності учасників.

\section{Література}

1. Валуев С. А. Организационный менеджмент : [уч. пособие] / С. А. Валуев, А. В. Игнатьева. - М. : Проспект, 2005. - 190 с. 2. Грішнова О. А. Економіка праці та соціально-трудові відносини: [підручник]/ О. А. Грішнова. - К., 2004.[Електронний ресурс] - Режим доступу: http://pidruchniki.ws. 3. Єгорова В. С. Культура мовлення сучасної молоді / В. С. Єгорова // Дослідження з лексикології і граматики української мови, 2012. - Вип.9. - С. 74-78. 4. Жуков Ю. М. Коммуникативный тренинг / Ю. М. Жуков. - М. : Гардарики, 2003. - 223 с. 5. Нестерева Э. Социальное партнерство и коллективное трудовое право / Э. Нестерева // Российская юстиция, 2004. - № 1. - C. 26. 7. Подоляк Л. Г. Психологія вищої школи : [підручник] / Л. Г. Подоляк, В. І. Юрченко. - К. : Каравела, 2008. - 352 с. 8. Семигин Г. Ю. Социальное партнерство / Г. Ю. Семигин. - М.: Из-во «Мысль», 1996. - 206 с. 9. Тищенко В. А. Классификация коммуникативных умений студентов / В. А. Тищенко // Знание. Понимание. Умение. - [Електронний ресурс] - Режим доступу: www.lib.znate.ru 10. Ткач Л. Культура мови як важливий чинник підготовки фахівцівдокументознавців / Л. М. Ткач, І. В. Рибалко // Дослідження 3 лексикології i граматики української мови, 2010. - Вип. 9. - С. 291-302. 11. Яшенкова О. В. Основи теорії мовної комунікації : [навч. посіб. для самост. роботи студента] / О. В. Яшенкова. - К. : ВЦ «Академія», 2011. - 304 с. 